\title{
ANALISIS KELAYAKAN FINANSIAL USAHA BUBUK KOPI PINANG INSTAN (STUDI KASUS CV.SIWAHRADJA) DI DESA GEULANGGANG KOTA JUANG KABUPATEN BIREUEN
}

\author{
Financial Feasibility Analysis of Instan Pinang Coffe Powder Business (CV. \\ Siwahradja Case Study) in Geulanggang Baro Village, Juang City, Bireuen Regency \\ Raudhatul Jannah, Rasdiansyah, Yusriana* \\ ${ }^{1}$ Program Studi Teknologi Hasil Pertanian, Fakultas Pertanian, Universitas Syiah Kuala \\ *Corresponding author: yuriana@unsyiah.ac.id
}

\begin{abstract}
Abstrak. Hasil penelitian pada strategi pemasaran menggunakan metode marketing mix (4P) dimana dalam satu kotak berisi 10 sachet dan memiliki harga Rp 150.000 per kotak. Promosi juga dilakukan salah satunya yaitu lewat media sosial seperti instagram (@siwahradja) sehingga dapat dikatakan industri rumahan ini layak untuk dijalankan dari segi pasar dan pemsaran. Pada aspek finansial didapatkan Net Present Value pada tahun ke-4 sebesar Rp. 4.165.687.998, nilai Internal Rate of Return sebesar 40,54\%, Payback Periode pada tahun ke-1 bulan ke-2 hari ke- 23, nilai Net Benefit Ratio sebesar 5,15, nilai Break Even Point, sebesar Rp 1.584.512.076 dan nilai Rasio Kontribusi Margin sebesar 78\%. Pada analisis sensitivitas variabel yang digunakan asumsi cost (naik) 5\% dan benefit (turun) 5\%. Pada asumsi I). Dimana biaya produksi naik 5\% didapatkan NPV sebesar Rp 3.698.397.280, IRR 51,98\%, maka usaha ini tetap layak untuk dilanjutkan karena (R > r) atau IRR masih mampu untuk menutupi bunga bank yaitu 12\%, PP didapatkan pada 1 tahun, 4 bulan, 29 hari. Pada asumsi II). Dimana keadaan biaya produksi turun 5\% didapatkan NPV sebesar Rp 4.685.848.860, IRR 59,91\%, maka usaha ini tetap layak untuk dilanjutkan karena $(\mathrm{R}>\mathrm{r})$ atau IRR masih mampu untuk menutupi bunga bank yaitu $12 \%$, PP didapatkan pada 1 tahun.
\end{abstract}

Kata kunci : Kopi pinang, Analisis finansial, Kriteria kelayakan usaha

\begin{abstract}
The results of research on marketing strategies using the marketing mix method (4P) where in one box contains 10 sachets and has a price of Rp. 150.000 per box. Promotion also carried out through social media such as instagram (@siwahradja) so it can be said that this cottage industry is feasible to run from a market and marketing perspective. In financial aspect, the Net Present Value in the $4^{\text {th }}$ year was Rp. 4.165.687.998 the value of the Internal Rate of Return is $40.45 \%$, the Payback Period in the $1^{\text {st }}$ year of the $2^{\text {nd }}$ month of the $23^{\text {rd }}$ day, the value og the Net Benefit Ration is 5.15, the balue of the Break Even Point is about Rp. 1.584.512.067 and the Contribution Margin Ratio is 78\%. In the sensitivity analysis of the variables used the assumption of cost (increase) 5\% and benefit (decrease) 5\%. On assumption I). Where production costs increase by 5\%, NPV ie $R p .3 .698 .397 .280$, IRR 51,98\%, then this business is still feasible tk continue because $(R>r)$ or IRR is still able to cover bank interest, which is $12 \%, P P$ is obtained in 1 year, 4 months, and 29 days. On assumtion II). Where the state of production costs decreased by 5\%, the NVP was Rp. 4.685.848.860, IRR 5991\%, then this businessis still feasible to continue because $(R>r)$ or IRR is still able to cover bank interest, which is $12 \%$, PP is obtained at 1 year.
\end{abstract}

Keywords: Areca coffee, Financial analysis, Business feasibility criteria

\section{PENDAHULUAN}

Kopi merupakan salah satu hasil komoditi perkebunan yang memiliki nilai ekonomis yang cukup tinggi diantara tanaman perkebunan lainnya dan berperan penting sebagai sumber devisa Negara. Pada tahun 2007-2013 Indonesia mengalami kenaikan yang cukup pesat, yaitu produksi kopi mencapai sekitar 2,17\% (Badan Pusat Statistik, 2015). Upaya meningkatkan daya saing dalam produktivitas dan mutu kopi terus dilakukan sehingga dapat bersaing di pasar dunia (Rahardjo, 2012). 
Kopi bisa diolah menjadi berbagai macam produk seperti minuman, makanan bahkan ada juga yang menjadikan bahan baku untuk pembuatan produk kosmetik. Kopi ini diolah menjadi minuman herbal instan yang dicampur

pinang. Olahan kopi dicampur pinang menjadikan cita rasa kopi menjadi lebih kelat dan pedas, selain kopi dan pinang dalam minuman ini juga memiliki rempah-rempah lainnya seperti kapulaga, cengkeh, jahe merah, lada putih, kayu manis, daun sirih, jeruk perut dan gula. Inovasi baru ini dikembangkan oleh salah seorang warga kabupaten Bireuen yang disebut dengan "Kopi Pinang Siwahradja". Penambahan biji pinang bertujuan untuk menambah cita rasa herbal dan juga dapat mengobati sakit lambung dan meningkatkan daya tahan tubuh. Produk kopi pinang ini masih berbasis industri rumahan.

Dalam membangun sebuah industri terdapat beberapa faktor yang perlu dipertimbangkan, seperti modal usaha, ketersediaan bahan baku, lokasi perusahaan, pekerja, alat yang digunakan dan lain sebagainya. Adapun salah satu cara yang dapat digunakan untuk menentukan keberhasilan suatu perusahaan industri yang akan dibangun yaitu dengan melakukan studi kelayakan usaha. Studi kelayakan usaha yaitu kegiatan mengevaluasi, menganalisis dan menilai layak atau tidaknya suatu industri untuk dijalankan (Jumingan, 2009).

\section{METODE PENELITIAN}

Penelitian ini dilaksanakan di CV. Siwahradja di Desa Geulanggang Baro, Kota Juang, Kabupaten Bireuen. Penelitian ini dilakukan pada bulan November 2020 - Maret 2021.

\section{MATERI DAN METODE}

\section{Metode Penelitian}

Penelitian ini dilakukan dengan menggunakan jenis penelitian deskriptif. penelitian deskriptif terbagi dua yaitu kuantitatif dan kualitatif. Penelitian deskriptif dilakukan dengan cara menghitung pada aspek finansial dengan beberapa kriteria kelayakan investasi, selain itu juga dibutuhkan untuk menghitung biaya investasi, biaya depresiasi, biaya operasional dan proyeksi pendapatan. Penelitian deskriptif kualitatif dengan cara memberikan penjelasan dan gambaran pada aspek-aspek lainnya.

\section{Teknik Analisis Data}

Data kuantitatif yang diperoleh dilakukan untuk mengetahui karakteristik usaha kopi pinang, data kuantitatif digunakan persamaan analisis ekonomi sebagai berikut :

1. Net Present Value (NPV)

$$
\begin{gathered}
\mathrm{NPV}=\sum_{t-1}^{n} \frac{R_{1}}{(1+\mathrm{i})^{\mathrm{t}}}-\mathrm{R}_{0} \\
\mathrm{NPV}=\mathrm{R}_{1} /(1+\mathrm{i})+\mathrm{R}_{2} /(1+\mathrm{i})^{2}+\mathrm{R}_{3} /(1+\mathrm{i})^{3}+\mathrm{R}_{4} /(1+\mathrm{i})^{4}-\mathrm{R}_{0}
\end{gathered}
$$

Keterangan:

NPV $=$ Net Present Value atau nilai sekarang

$\sum=$ Simbol untuk penjumlahan

$\mathrm{t}=$ Periode waktu atau tahun ke $\mathrm{t}$

$\mathrm{n}=$ Umur usulan usaha

$\mathrm{R}_{1}=$ Aliran kas pada tahun ke $\mathrm{t}$ 
$\mathrm{R}_{0}=$ Modal investasi awal

Kriteria untuk menerima dan menolak rencana investasi dengan metode NPV adalah sebagai berikut:

- Apabila NPV > 0, maka usulan industri akan diterima

- Apabila NPV < 0, maka usulan industri akan ditolak, dan

- Apabila NPV = 0, maka kemungkinan usaha kopi pinang akan diterima atau nilai perusahaan tetap walaupun usulan usaha kopi pinang diterima atau ditolak.

2. Internal Rate of Return (IRR)

$$
\mathrm{IRR}=\mathrm{i}_{1}+\frac{N P V 1}{N P V 1-N P V 2}\left(\mathrm{i}_{1}-\mathrm{i}_{2}\right)
$$

Keterangan:

IRR $=$ Tingkat pengembalian internal

$\mathrm{i}_{1}=$ Discount faktor (tingkat bunga) yang menghasilkan NPV positif

$\mathrm{i}_{2}=$ Discount faktor (tingkat bunga) yang menghasilkan negatif

$\mathrm{NPV}_{1}=$ Nilai sekarang yang positif

$\mathrm{NPV}_{2}=$ Nilai sekarang yang negative

Kriteria:

- $\quad$ IRR > r, usaha kopi pinang layak/untung

- IRR < r, usaha kopi pinang tidak layak/rugi

- $\quad$ IRR $=r$, usaha kopi pinang berada pada titik impas.

3. Net Benefit Cost (Net B/C)

Net $\frac{B}{C}=\frac{N P V}{\text { investasi awal }}$

Keterangan:

Net $\mathrm{B} / \mathrm{C}=$ Net Benefit Cost

$\mathrm{Bt}=$ Manfaat (Benefit) pada tahun ke-t $(\mathrm{Rp})$

$\mathrm{Ct}=$ Biaya $($ Cost $)$ padatahun ke-t $(\mathrm{Rp})$

$\mathrm{I}=$ Tingkat suku bunga yang berlaku (\%)

$\mathrm{n}=$ Lamanya periode waktu (tahun)

$\mathrm{t}=$ Umur proyek

Kriteria Net B/C Ratio yaitu:

- Jika Net B/C > 1, maka usaha kopi pinang dikatakan layak untuk diusahakan.

- Jika Net $\mathrm{B} / \mathrm{C}<1$, maka usaha kopi pinang dikatakan tidak layak untuk diusahakan

- Jika Net $\mathrm{B} / \mathrm{C}=1$, maka usaha kopi pinang dalam keadaan cash in flows sama dengan cash out flows dalam present value disebut dengan Break Even Point (BEP), yaitu total cost sama dengan total revenue

4. Payback Periode (PP)

$$
\mathrm{PP}=\frac{\mathrm{T}_{\mathrm{p}-1}+\sum_{i=1}^{n} I_{\mathrm{i}}-\sum_{i=1}^{n} B \text { icp }}{\mathrm{B}_{\mathrm{p}}}-1
$$


Keterangan:

$\mathrm{PP}=$ Payback Periode

$\mathrm{T}_{\mathrm{p}-1}=$ Tahun sebelum dapat $\mathrm{PP}$

$\mathrm{I}_{\mathrm{i}}=$ Jumlah investasi telah didiskon

$\mathrm{B}_{\text {icp -1 }}=$ Jumlah benefit yang telah didiskon sebelum PP

Kriteria:

- Semakin besar nilai PP, semakin lama pengambilan investasi yang ditanamkan pada usaha kopi pinang

- Semakin kecil nilai PP, semakin cepat pengambilan investasi yang ditanamkan pada usaha kopi pinang.

5. Break Even Point (BEP)

BEP Rupiah

$$
\mathrm{BEP}=\frac{\text { Total biaya tetap }}{1-\frac{\text { Biaya variable cost setiap unit produk }}{\text { Harga jual per unit }}}
$$

BEP Unit

$$
\mathrm{BEP}=\frac{\text { Total biaya tetap }}{\text { Harga jual per unit-Biaya variable cost setiap unit produk }}
$$

6. Return On Investment (ROI)

$$
\mathrm{ROI}=\frac{(\text { Total penjualan-Investasi) }}{\text { Investasi }} \times 100 \%
$$

7. Rasio Kontribusi Margin

$$
\mathrm{RKM}=\frac{\text { contribusi } \text { margin }}{\text { harga jual produk }}
$$

8. Analisis Sensitifitas

Analisis sensitivitas dilakukan untuk melihat dampak yang ditimbulkan dari perubahan kondisi diluar jangkauan asumsi yang telah dibuat pada saat perencanaan.

Asumsi-asumsi sebagai berikut:

- Apabila terjadi kenaikan harga bahan baku, hal ini diasumsikan dengan pertimbangan persentase faktor produksi yang paling tinggi dan rata-rata persentase kenaikan pada tahun sebelumnya.

- Apabila terjadi penurunan skala produksi penurunan diasumsikan dengan pertimbangan semakin besarnya biaya produksi yang harus dikeluarkan pada usaha tersebut.

\section{HASIL DAN PEMBAHASAN}

\section{Aspek Pasar dan Pemasaran}

Pemasaran merupakan kegiatan manusia yang diarahkan untuk memenuhi kebutuhan dan keinginan konsumen melalui pertukaran. Strategi yang digunakan pada aspek pasar ini yaitu metode marketing mix 4P (Product, Price, Place and Promotion). Keempat unsur bauran pemasaran ini berhubungan satu sama lain, sehingga harus diupayakan untuk menghasilkan satu kebijakan pemasaran yang mengarah kepada layanan efektif. 
Produk kopi pinang ini diproduksi masih semi manual dan sederhana, sehingga tidak mengalami banyak kendala. Hasil produk kopi pinang yang dipasarkan dikemas dalam kotak, satu kotak berisi 10 sachet, memiliki harga Rp. 150.000 per kotak, produk dipasarkan secara online maupun langsung ke konsumennya.

\section{Aspek Teknis}

Aspek teknis lokasi produksi menjalankan Industri Rumahan Kopi Pinang "Siwahradja" beralamat di Desa Geulanggang Baro, Kota Juang, Kabupaten Bireuen. Bahan baku yang diperlukan dalam proses produksi ini yaitu bubuk kopi dan bubuk pinang. Bahan tambahan yang digunakan berupa rempah-rempah seperti kapulaga, cengkeh, jahe merah, lada putih, kayu manis, daun sirih, jeruk perut dan gula. Bahan penolong yang digunakan dalam proses pengemasan produk antara lain aluminium foil dan kotak kardus. Harga bahan baku bubuk berkisar antara Rp 50.000 per kilogram.

\section{Aspek Manajemen}

Analisis aspek manajemen dan organisasi bertujuan untuk mengetahui usaha yang akan dijalankan dapat dibangun dengan tepat waktu. Aspek ini juga menganalisis ketersediaan sumber daya manusia yang berkompeten sehingga usaha yang akan dibangun dapat dijalankan.

Tabel 1. Jumlah Tenaga Kerja pada industri rumahan produk kopi pinang

\begin{tabular}{|c|c|c|c|c|c|}
\hline \multirow{2}{*}{ No. } & \multirow{2}{*}{ Uraian Pekerjaan } & \multicolumn{4}{|c|}{ Jumlah (Orang) } \\
\hline & & Tahun 2017 & Tahun 2018 & Tahun 2019 & Tahun 2020 \\
\hline 1. & Manager & 1 & 1 & 1 & 1 \\
\hline 2. & Kepala Bidang & 1 & 1 & 1 & 1 \\
\hline 3. & Kepala Bagian & 1 & 1 & 1 & 1 \\
\hline 4. & Teknisi/Operator Mesin & 1 & 2 & 3 & 3 \\
\hline 5. & Staf Bagian Umum & 2 & 2 & 2 & 2 \\
\hline 6. & Staf Bagian Pemasaran & 3 & 3 & 3 & 3 \\
\hline
\end{tabular}

Berdasarkan tabel diatas terdapat penambahan karyawan bagian teknisi/operator mesin pada tahun 2018 sebanyak satu orang dan 2019 satu orang. Jumlah tersebut disesuaikan dengan kebutuhan industri, ini dikarenakan banyaknya permintaan pasar sehingga bertambah juga jumlah produksi setiap tahunnya. Tenaga kerja yang diterima pada Industri Rumahan Produk Kopi Pinang ini mengutamakan warga setempat yang memiliki kemampuan dan pekerja keras.

Struktur organisasi yang sederhana memudahkan pelaksanaan tugas dan tanggung jawab masing-masing bagian dalam Industri Rumahan Kopi Pinang. Adapun bentuk struktur organisasi yang digunakan pada Industri Rumahan Produk Kopi Pinang ini yaitu struktur organisasi lini dan staf.

\section{Aspek Hukum}

Usaha Industri Rumahan Produk Kopi Pinang ditinjau dari aspek hukum merupakan kegiatan usaha yang legal karena tidak bertentangan dengan hukum yang berlaku serta mendapatkan izin oleh pemerintah setempat yaitu Kabupaten Bireuen. Untuk kondisi rencana pengembangan sudah mendapat perizinan usaha dari BPOM seperti pelabelan halal, data kemasan dan izin Produksi dikarenakan setelah kondisi pengembangan usaha, perizinan dari BPOM sangat penting dilakukan, karena tanpa adanya label perizinan dari BPOM maka produk yang akan diproduksi susah untuk diterima dikalangan masyarakat luas dikarenakan tidak ada 
jaminan yang jelas untuk produk. Berdasarkan analisis aspek hukum usaha Industri Rumahan Produk Kopi Pinang pada kondisi rencana pengembangan ini dikatakan layak.

\section{Aspek Lingkungan}

Aspek lingkungan mempelajari bagaimana pengaruh bisnis tersebut terhadap lingkungan. Perlunya analisis dampak lingkungan dilakukan karena dapat memberikan gambaran kepada pelaku usaha tentang dampak yang dapat ditimbulkan suatu usaha terhadap lingkungan jika dijalankan. Lingkungan merupakan komponen yang terkena dampak secara langsung dan pertama kali dari adanya usaha Industri Rumahan Produk Kopi Pinang ini.

Produk kopi pinang memang menghasilkan limbah berupa sisa kulit yang dikupas dari pinangnya, namun limbah limbah tersebut tidak mengganggu masyarakat sekitar karena dapat digunakan sebagai pakan ternak atau dapat dibuang karena akan mudah terurai didalam tanah.

Hasil dari analisis aspek lingkungan dapat dikatakan bahwa usaha Industri Rumahan Produk Kopi Pinang ini tidak bermasalah yang dapat menghambat jalannya usaha sehingga dapat dikatakan layak untuk dijalankan.

\section{Analisis Finansial}

Aspek ini membahas dana yang dibutuhkan atau dikeluarkan untuk usaha dan seluruh pendapatan yang akan diperoleh oleh Industri Rumahan Produk Kopi Pinang.

\section{Arus pengeluaran}

Arus pengeluaran adalah seluruh biaya yang dikeluarkan oleh perusahaan dalam tahap awal pembangunan produk kopi pinang, biaya yang dimaksud seperti biaya investasi pembangunan terdiri dari biaya perizinan, biaya tanah dan bangunan, biaya peralatan utama dan biaya peralatan pendukung, dan juga biaya operasional.

Biaya perizinan adalah biaya yang dikeluarkan untuk pengurusan izin-izin dalam pembangunan usaha produk kopi pinang. Perizinan usaha kopi pinang meliputi beberapa syarat dan berkas seperti Tanda Daftar Perusahaan Rp 500.000 Surat Izin Usaha Perdagangan Rp 500.000 Surat Izin Usaha Industri Rp 500.000 Izin Mendirikan Usaha Rp 2.500.000 dan Akte Perusahaan Rp 8.000.000 dari keseluruhan dapat disimpulkan bahwa pendirian industri rumahan produk kopi pinang sebesar Rp12.000.000.

Biaya tanah dan bangunan perusahaan memiliki beberapa aspek dan harga masingmasingnya, seperti tanah Rp 112.500.000, ruang kantor 94.500.000, ruang mushalla 33.750.000, ruang kantin Rp 17.500.000 ruang bahan baku dan processing Rp 180.000.000, ruang security $\mathrm{Rp}$ 6.000.000, ruang genset $\mathrm{Rp}$ 6.750.000, area limbah kering $\mathrm{Rp}$ 6.750.000, pagar 52.200.000 sehingga total keseluruhan untuk biaya tanah dan pembangunan Rp 509.950.000. Harga atau biaya berikut untuk menjadi acuan bagi investor yang ingin menaruh sahamnya pada industri rumahan Kopi Pinang ini.

Usaha produk kopi pinang hanya memiliki tiga buah mesin dalam melakukan proses pengolahannya. Dapat diketahui dari tabel diatas harga mesin masing-masingnya yaitu mesin rosting dengan harga $\mathrm{Rp}$ 115.000.000, mesin grinding $\mathrm{Rp} 19.650 .000$ dan mesin pengemas dengan harga Rp 12.750.000, dengan keseluruhan harga total sebesar Rp 147.400.000.

Biaya peralatan pendukung Industri Rumahan Produk Kopi Pinang dalam menunjang produksi kopi pinang itu sendiri, terdapat beberapa biaya peralatan pendukung seperti mobil box, motor, instalasi listrik hingga sepatu bot dengan kisaran harga berbeda-beda satu dengan yang lainnya. Total harga yang didapatkan dari keseluruhan biaya peralatan pendukung industri sebesar Rp 287.600.000. 
Biaya operasional pada indsutri rumahan produk kopi pinang terbagi dua yaitu biaya tetap (fixed cost) dan biaya tidak tetap (variable cost).

Tabel 2. Biaya pengeluaran Industri Rumahan Produk Kopi Pinang

\begin{tabular}{ccrcrr} 
& & \multicolumn{2}{c}{ Biaya tetap } & \multicolumn{2}{c}{ Biaya tidak tetap } \\
\cline { 3 - 6 } Tahun & $\begin{array}{c}\text { Biaya investasi } \\
(\mathrm{Rp})\end{array}$ & $\begin{array}{c}\text { Total biaya } \\
\text { per bulan (Rp) }\end{array}$ & $\begin{array}{c}\text { Total biaya per } \\
\text { tahun }(\mathrm{Rp})\end{array}$ & $\begin{array}{c}\text { Total biaya per } \\
\text { bulan }(\mathrm{Rp})\end{array}$ & $\begin{array}{c}\text { Total biaya per } \\
\text { tahun }(\mathrm{Rp})\end{array}$ \\
\hline 0 & 956.950 .000 & & & & \\
1 & & 20.950 .000 & 251.400 .000 & 14.559 .780 & 17.717 .365 \\
2 & & 24.753 .000 & 297.036 .000 & 16.750 .227 & 201.002 .729 \\
3 & & 28.864 .000 & 346.368 .000 & 17.905 .974 & 214.871 .689 \\
4 & & 30.621 .000 & 367.452 .000 & 19.017 .353 & 228.208 .230 \\
\hline Total & 956.950 .000 & 105.188 .000 & 1.262 .256 .000 & 68.233 .334 & 818.800 .014 \\
\hline
\end{tabular}

Berdasarkan tabel di atas, biaya investasi yang dikeluarkan oleh usaha Kopi Pinang CV. Siwahradja yaitu sebesar Rp 956.950.000 meliputi biaya perizinan usaha, tanah dan bangunan biaya, pembelian mesin dan peralatan serta biaya promosi.

\section{Arus Penerimaan}

Arus penerimaan adalah selisih dari nilai produksi yang dijual dan biaya yang dikeluarkan dalam penjualan produk dalam kurun waktu tertentu. Arus penerimaan meliputi jumlah produksi, harga jual produk, nilai produksi serta keuntungan bersih yang akan menjadi acuan untuk melihat tingkat penerimaan suatu usaha.

Tabel 3. Jumlah produksi dan nilai produksi industri rumahan produk kopi pinang

\begin{tabular}{cccr}
\hline Tahun & Jumlah produksi (Pcs/tahun) & $\begin{array}{c}\text { Harga jual } \\
(\mathrm{Rp} / \mathrm{Pcs})\end{array}$ & $\begin{array}{c}\text { Total produksi } \\
\text { (Rp/tahun) }\end{array}$ \\
\hline 0 & & & \\
1 & 14.400 & 135.000 & 1.944 .000 .000 \\
2 & 16.800 & 150.000 & 2.520 .000 .000 \\
3 & 18.000 & 150.000 & 2.700 .000 .000 \\
4 & 19.200 & 150.000 & 2.880 .000 .000 \\
\hline Total & 64.400 & & 10.044 .000 .000 \\
\hline
\end{tabular}

Berdasarkan tabel diatas, jumlah produksi kopi pinang meningkat. Total jumlah produksi dari tahun pertama hingga terakhir sebanyak 64.400 pcs, maka total produksi kopi pinang yang dihasilkan oleh Industri Rumahan Produk Kopi Pinang selama 4 tahun terakhir yaitu sebesar Rp. 10.044.000.000.

\section{Kriteria kelayakan investasi}

Tabel 5. Nilai kriteria investasi industri rumahan produk kopi pinang

\begin{tabular}{llr}
\hline No. & \multicolumn{1}{c}{ Kriteria investasi } & \multicolumn{1}{c}{ Nilai } \\
\hline 1. & Net Present Value (NPV) & 4.005 .883 .123 \\
2. & Internal Rate of Return (IRR) & $40,54 \%$ \\
3. & Payback Period (PP) & 1 tahun 2 bulan 23 hari \\
4. & Return On Investment & $86,66 \%$ \\
5. & Net Benefit Ratio (Net B/C) & 5,15 \\
6. & Break Even Poin (BEP) & 1.584 .512 .076 \\
7. & Rasio Kontribusi Margin (RKM) & $78 \%$ \\
\hline
\end{tabular}

\section{Net present value (NPV)}


Berdasarkan hasil analisis kelayakan usaha pada tingkat suku bunga bank yang berlaku saat penelitian adalah 12,5\% selama 4 tahun didapatkan nilai NPV sebesar Rp 4.005.883.123. Berdasarkan syarat kriteria kelayakan NPV > 0, maka usaha Industri Rumahan Produk Kopi Pinang layak untuk dijalankan. NPV dihitung berdasarkan suku bunga atau Discount Factor $(D F)$.

\section{Internal Rate of Return (IRR)}

Internal Rate Of Return ditentukan dengan cara mencoba beberapa DF untuk mendapatkan nilai NPV sama dengan nol dengan ditentukan DF 12,5\%. Dari hasil perhitungan diperoleh nilai IRR sebesar 40,54\%, sedangkan pinjaman yang diberikan oleh pihak Bank yaitu 12,5\% yang artinya perhitungan IRR lebih besar daripada diskonto (r), maka rencana investasi tersebut dapat dilanjutkan. Sehingga dapat dsimpulkan bahwa pendirian Industri Rumahan Produk Kopi Pinang ini berdasarkan hitungan IRR layak untuk dijalankan.

\section{Payback periode (PP)}

Payback Period dihitung berdasarkan jangka waktu yang dibutuhkan untuk mengembalikan modal investasi suatu proyek dengan menggunakan cash flow yang dihasilkan proyek tersebut. Berdasarkan hasil perhitungan diperoleh hasil PP yaitu selama 1 tahun 2 bulan 23 hari. Periode proyek yang direncanakan yaitu selama 2 tahun, sehingga dapat disimpulkan pendirian Industri Rumahan Produk Kopi Pinang berdasarkan hitungan Payback Period layak untuk dijalankan.

\section{Return on investment (ROI)}

Return On Investment menunjukkan pengembalian atas modal investasi dimana besarnya menfaat bersih setelah pajak yang dicapai dibagi dengan besarnya modal investasi.. Berdasarkan hasil perhitungan ROI dapat diketahui bahwa laba investasi atau keuntungan yang didapatkan setelah pengembalian modal dalam usaha Kopi Pinang CV. Siwahradja ini yaitu sebesar $67,54 \%$. Sehingga pengembalian modal investasi ini terbilang cepat dan layak untuk dijalankan.

\section{Net benefit cost (Net B/C)}

Net Benefit Cost dihitung berdasarkan perbandingan antara tingkat suatu keutungan yang diperoleh dengan total biaya yang dikeluarkan. Berdasarkan hasil perhitungan diperoleh nilai (Net B/C) yaitu 5,15. Hasil tersebut terlihat bahwa $($ Net B/C) $>1$. Sehingga dapat disimpulkan bahwa pendirian Industri Rumahan Produk Kopi Pinang layak untuk dijalankan.

\section{Break Even Point (BEP)}

Break Even Point adalah titik impas dimana posisi jumlah pendapatan biaya sama atau seimbang sehingga tidak terdapat keuntungun ataupun kerugian dalam suatu perusahaan. BEP digunakan untuk menganalisa proyeksi sejauh mana banyaknya jumlah unit yang diproduksi yang diproduksi atau sebanyak apa uang yang harus diterima untuk mendapatkan titik impas balik modal. Berdasarkan hasil perhitungan maka dapat disimpulkan Industri Rumahan Produk Kopi Pinang menemukan titik impas pada saat memperoleh keuntungan sebesar Rp 1.091.037.735,8 dan pada jumlah produk sebanyak 7.278 unit.

\section{Rasio kontribusi margin}


Rasio Kontribusi Margin adalah untuk menentukan tingkat penjualan yang diperlukan guna mendapat laba yang diinginkan (target laba bersih). Berdasarkan hasil perhitungan maka dapat disimpulkan Industri Rumahan Produk Kopi Pinang mendapatkan laba bersih pada 78\%

\section{Analisis sensitivitas}

Variabel yang digunakan untuk analisis sensitivitas pada penelitian ini meliputi kenaikan biaya produksi dan penurunan biaya produksi sebesar $5 \%$. Kenaikan dan penurunan biaya produksi ataupun biaya operasional didasarkan pada data inflasi yang terjadi berada dikisaran $3-5 \%$.

Asumsi I, apabila biaya produksi (cost) naik 5\% sedangkan penerimaan (benefit) tetap. Berdasarkan asumsi pertama dari analisis sensitivitas dimana keadaan biaya produksi naik 5\% didapatkan NPV sebesar Rp 3.462.131.824, IRR 51,98\%, maka usaha ini tetap layak untuk dilanjutkan karena $(\mathrm{R}>\mathrm{r}$ ) atau IRR masih mampu untuk menutupi bunga bank yaitu $12 \%$, PP didapatkan pada 1 tahun, 4 bulan, 29 hari, nilai ROI pada asumsi ini yaitu 57,19\% dari biaya investasi, Net (B/C) pada 4,95. BEP yang diperoleh sebesar Rp 1.064.172.120,8. RKM pada 57\%. Usaha ini masih layak untuk dijalankan karena semua kriteria investasi memenuhi syarat.

Asumsi II, apabila penerimaan (benefit) turun 5\%. Berdasarkan asumsi kedua dari analisis sensitivitas dimana keadaan biaya produksi turun 5\% didapatkan NPV sebesar Rp 4.685.848.860, IRR 59,91\%, maka usaha ini tetap layak untuk dilanjutkan karena (R > r) atau IRR masih mampu untuk menutupi bunga bank yaitu 12\%, PP didapatkan pada 1 tahun, nilai ROI pada asumsi ini yaitu $64,13 \%$ dari biaya investasi, Net (B/C) pada 6,79. BEP yang diperoleh sebesar Rp 1.049.172.622,9 dan nila RKM didapatkan sebesar 64\%. Usaha ini masih layak untuk dijalankan karena semua kriteria investasi memenuhi syarat.

\section{KESIMPULAN}

Pada aspek finansial, pendirian industri rumahan produk kopi pinang di Kabupaten Bireuen layak untuk dijalankan berdasarkan kriteria investasi yaitu nilai Net Present Value pada tahun ke-4 sebesar Rp. 4.005.883.123, nilai Internal Rate of Return sebesar 40,54\%, Payback Periode pada tahun ke-1 bulan ke-2 hari ke- 23, nilai Net Benefit Ratio sebesar 5,15, nilai Break Even Point, sebesar Rp 1.584.512.076 dan nilai Rasio Kontribusi Margin sebesar 78\%. Pada analisis sensitivitas variabel yang digunakan asumsi cost (naik) 5\% dan benefit (turun) 5\%. Pada asumsi I). Dimana biaya produksi naik 5\% didapatkan NPV sebesar Rp 3.462.131.824, IRR 51,98\%, maka usaha ini tetap layak untuk dilanjutkan karena $(\mathrm{R}>\mathrm{r}$ ) atau IRR masih mampu untuk menutupi bunga bank yaitu 12\%, PP didapatkan pada 1 tahun, 4 bulan, 29 hari. Pada asumsi II). Dimana keadaan biaya produksi turun 5\% didapatkan NPV sebesar Rp 4.685.848.860, IRR $59,91 \%$, maka usaha ini tetap layak untuk dilanjutkan karena ( $\mathrm{R}>\mathrm{r}$ ) atau IRR masih mampu untuk menutupi bunga bank yaitu 12\%, PP didapatkan pada 1 tahun.

\section{DAFTAR PUSTAKA}

Afnita. 2002. Analisis Kelayakan Investasi Paprika dengan Sistem Pertanian Organik di PT Austindo Mitra Sarana Farm. Skripsi. Jurusan Ilmu-Ilmu Sosial Ekonomi Pertanian, Fakultas Pertanian, Institut Pertanian Bogor, Bogor. 
Ayu, S. E. S. 2014. Pengembangan Industri Gelatin Tulang Ikan Bandeng di Kabupaten Kendal, Jawa

Tengah. Skripsi. Jawa Tengah.

Badan Pusat Statistik. 2015. Produksi Kopi Di Indonesia. Badan Pusat Statistik, Jakarta.

Budiasih, Yanti. 2012. Statistik Deskriptif untuk Ekonomi dan Bisnis. Jelajah Nusa, Tangerang.

David, Fred R. 2009, Manajemen Strategis. Salemba Empat Jakarta.

Dinas Perkebunan Provinsi Jambi, 2016. Statistik Perkebunan. Provinsi Jambi Tahun 2015.

Husnan, S. dan Muhammad. 2000. Studi Kelayakan Proyek. Unit Penerbit dan Percetakan AMP YKPN, Yogyakarta.

Ibrahim, Y. 2009. Studi Kelayakan Bisnis. Rineka Cipta, Jakarta.

Ihsanurrozi, M. 2014. Perbandingan Jumlah Anak dari Mencit Betina yang Dikawinkan dengan Mencit Jantan yang Mendapat Perlakuan Jus Biji Pinang Muda dan Jus Daun Jati Belanda. Skripsi. Jurusan Pendidikan Biologi. Universitas Pendidikan Indonesia.

Jaiswal, Rakesh., Maria A Patras., Pinkie J. E., Nikolai Kuhnert. 2010. Profile and Characterization of the Chlorogenic Acid in Green Robusta Coffee Beans by LC-MS : Identification Seven New Classes of Compounds. J. Agric. Food Chem. 2010;58(15) : 8722-8737.

Jumingan. 2009. Studi Kelayakan Bisnis. Cetakan pertama. Jakarta, Bumi Aksara.

Kasmir dan Jakfar. 2003. Studi Kelayakan Bisnis. Edisi 2. Prenada Media Group, Jakarta.

Kusmiati, A., dan Nursamsiyah, D.Y. 2015. Kelayakan Finansial Usaha Tani Kopi Arabika Dan Prospek Pengembangannya di Ketinggian Sedang. Jurnal Agriekonomika. 4(2): 223-235.

Maulidah, S., dan D.A. Pratiwi. 2010. Analisis Kelayakan Finansial Usahatani Anggur Prabu Bestari. Jurnal AGRISE 10 (3) : 218

Muin. M 2015. Petani dan Permasalahan Petani. Rajawali Press. Jakarta.

Najiyati, S., dan Danarti. 2004. Kopi Budidaya dan Penanganan Lepas Panen. Buku. Penebar swadaya. Jakarta.

Ngamel, A.K. 2012. Analisis Finansial Usaha Budidya Rumput Laut dan Nilai Tambah Tepung Karaginan di Kecamatan Kei Kecil, Kabupaten Maluku Tenggara. Jurnal Sains Terapan, Edisi II $2(1): 74$.

Nurcahyo, D.F. 2011. Analisis Kelayakan Bisnis (Studi Kasus di PT. Pemuda Mandiri Sejahtera). Skripsi Program Studi Teknik Industri Universitas Indonesia.

Nurmalina, R. Tintin S. Arif K. 2009. Studi Kelayakan Bisnis. Bogor. Departemen Agribisnis, Institut Pertanian Bogor.

Panggabean, Edy. 2011. Buku Pintar Kopi. Agromedia Pustaka. Jakarta

Rahardi dan Hartono. 2003. Agribisnis Peternakan. Penebar Swadaya, Jakarta.

Rahardjo, Pudji. 2012. Paduan Budi Daya Kopi dan Pengolahan Kopi Arabika dan Robusta. Penebar Swadaya. Jakarta.

Rangkuti, Freddy. 2006. Teknik Membuat Perancangan Bisnis dan Analisis Kasus. Gramedia Pustaka, Jakarta.

Rangkuti, F. 2002. Analisis SWOT : Teknik Membedah Kasus Bisnis. Gramedia. Jakarta.

Siagian, Sondang, 2005. Fungsi-fungsi Manajemen, Edisi keenam, PT. Bumi Aksara, Jakarta.

Siregar, L. F. 2009. Analisis Kelayakan Usaha Penyulingan Minyak Nilam (Patchouli oil) PT. Perkasa Primatama Mandiri Kabupaten Mandailing Natal Sumatera Utara. Skripsi. Departemen Agribisnis, Fakultas Ekonomi dan Manajemen, Institut Pertanian Bogor, Bogor.

Sulastri, L. 2016. Studi Kelayakan Bisnis Untuk Wirausaha. La Goods Publishing, Bandung. 